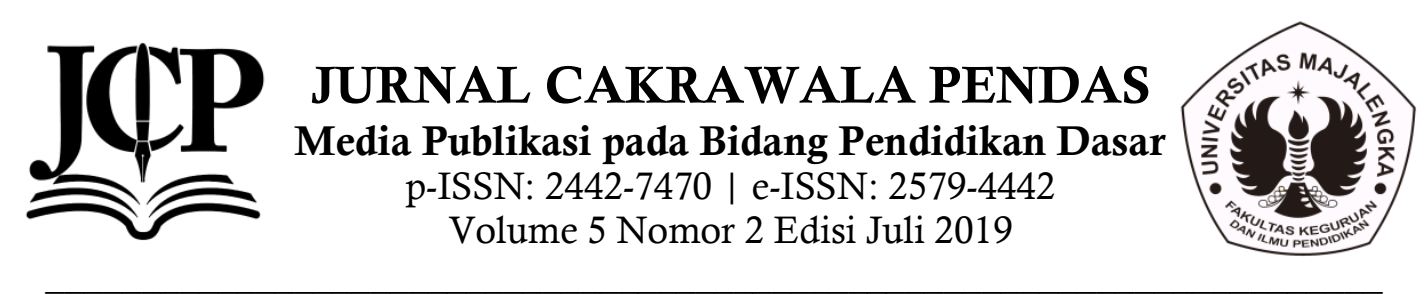

\title{
PEMBELAJARAN SAINS DI ERA REVOLUSI INDUSTRI 4.0
}

\author{
Yuyu Yuliati ${ }^{1}$, Dudu Suhandi Saputra ${ }^{2}$ \\ ${ }^{1}$ Universitas Majalengka, ${ }^{2}$ Universitas Majalengka \\ 1yuyuliati74@gmail.com
}

\begin{abstract}
Abstrak
Era revolusi industri 4.0 membawa konsekuensi terhadap pendidikan sains untuk mampu mempersiapkan individu yang memiliki kompetensi mumpuni dalam menghadapi berbagai tantangan di masa depan dengan mengaplikasikan kemajuan teknologi pada kegiatan pembelajaran. Kajian ini memberikan gambaran terhadap peranan pembelajaran sains di era revolusi industri 4.0. Hasil kajian menunjukan bahwa sains berkaitan erat dengan teknologi, selanjutnya bahwa sains memiliki peranan yang sangat besar dalam mempersiapkan sumber daya manusia yang unggul, baik secara soft skill maupun hard skill. Sains memiliki peranan dalam mendorong peserta didik untuk mampu mengaplikasikan pemahamannya akan sains dalam menghasilkan suatu karya teknologi yang bermanfaat dalam pemenuhan kebutuhan hidup manusia, hal tersebut mengingat karena teknogi merupakan aplikasi dari sains. Melalui sains peserta didik berlatih mengembangkan kemampuan berpikir sistematis, logis, dan kritis selanjutnya melalui sains peserta didik juga dilatih untuk melakukan penemuan dan rekayasa dengan menerapkan berbagai langkah kerja ilmiah.
\end{abstract}

Kata Kunci: Pembelajaran sains, revolusi industry 4.0

\begin{abstract}
The era of industrial revolution 4.0 brought consequences for science education to be able to prepare individuals who have qualified competencies in facing various challenges in the future by applying technological advances in learning activities. This study provides an overview of the role of science learning in the era of industrial revolution 4.0. The results of the study show that science is closely related to technology, science has a very large role in preparing superior human resources, both soft skills and hard skills. Science has a role in encouraging students to be able to apply their understanding of science to produce a technological work that is useful in meeting the needs of human life, this is because technology is an application of science. Through science students practice developing the ability to think systematically, logically, and critically then through science students are also trained to make discoveries and engineering by applying various steps of scientific work.
\end{abstract}

Key Words: Science Education, Industrial Revolution 4.0 


\section{Pendahuluan}

Pesatnya kemajuan teknologi informasi, komunikasi dan semakin kompleksnya tantangan masa depan menandai era baru yang disebut dengan era revolusi industri 4.0. Pada era ini, teknologi informasi telah menjadi basis dalam kehidupan manusia. Hal ini memberikan konsekuensi dan dampak yang nyata pada bidang pendidikan sains yang mana pendidikan sains harus didasarkan pada kebutuhan untuk memenuhi kebutuhan yang ada di masa depan melalui pemanfaatan teknologi. Pendidikan sains memiliki peranan untuk menghasilkan sumber daya manusia yang inovatif dan memiliki kompetensi unggul baik secara soft skill maupun hard skill sehingga dapat disejajarkan bahkan mampu bersaing dengan sumber daya manusia dari negara lain dalam menghadapi berbagai isu-isu global. Hal ini senada dengan pendapat Kanematsu \& Barry bahwa menyiapkan lulusan yang berkualitas dan mampu bersaing secara global, dan menguasai perkembangan teknologi merupakan hal yang penting untuk semua orang dan penting bagi masa depan suatu Negara (Subekti, H.,dkk, 2018). Sains sendiri merupakan salah satu ilmu pengetahuan yang memiliki peranan penting dalam kehidupan manusia yaitu ilmu pengetahuan yang mempelajari alam semesta dan segala isinya serta berbagai perubahan yang terjadi di dalamnya.

Pada hakikatnya sains dibangun atas dasar produk ilmiah, proses ilmiah, sikap ilmiah, dan aplikasi. Sains sebagai produk merupakan pengetahuan yang terdiri dari konsep, prinsip, hukum, dan teori. Proses sains terdiri dari keterampilanketerampilan proses untuk mendapatkan dan mengembangkan sains. Sikap ilmiah merupakan nilai karakter. Sedangkan aplikasi sains merupakan penerapan konsep sains yang bersifat abstrak dalam bentuk konkrit yang berupa teknologi. Antara sains dan teknologi merupakan dua hal yang saling terkait satu dengan yang lain karena sains secara umum merupakan pengetahuan yang didapatkan dengan cara sistematis tentang struktur dan perilaku dari segala fenomena yang ada di alam beserta isinya. Sedangkan teknologi merupakan aplikasi dari sains sebagai respons atas tuntutan manusia akan kehidupan yang lebih baik. Sains dan teknologi dapat berkembang melalui kegiatan penemuan dengan berbagai bentuk inovasi dan rekayasa. Pada era revolusi industri 4.0 perkembangan sains akan mendorong pada perkembangan teknologi yang menjadi salah satu basis dari hampir seluruh kegiatan manusia.

Pembelajaran sains menghendaki siswa untuk terlibat langsung secara aktif yang terimplikasikan dalam kegiatan secara fisik ataupun mental. Berdasarkan penjelasan tersebut, artinya bahwa pembelajaran sains tidak hanya mencakup aktivitas hands on tetapi juga minds on dalam mencari berbagai informasi terkait dengan berbagai fenomena alam melalui berbagai metode ilmiah.

Di tingkat SD/MI pembelajaran sains menekankan pada pembelajaran Salingtemas (Sains, lingkungan, teknologi, dan masyarakat) yang diarahkan pada pengalaman belajar untuk merancang dan membuat suatu karya melalui penerapan konsep sains dan kompetensi bekerja ilmiah secara bijaksana, dengan begitu melalui pemahaman sains yang didapat peserta didik dapat menyelesaikan berbagai permasalahan yang dialami dalam kehidupan sehari-hari. Namun sayangnya masih terdapat permasalahan dalam pembelajaran sains yang masih belum terselesaikan diantaranya yaitu untuk aspek konteks aplikasi sains terbukti hampir dapat dipastikan bahwa banyak peserta didik tidak mampu mengaitkan pengetahuan sains yang dipelajarinya dengan fenomenafenomena yang terjadi di kehidupan seharihari, karena peserta didik tidak memperoleh pengalaman untuk mengkaitkannya (Permatasari, 2016). Hal ini dikhawatirkan akan berdampak pada kualitas peserta didik secara keseluruhan yang mana pada akhirnya peserta didik akan mengalami kesulitan dalam bersaing dengan sumber daya manusia dari negara lain dalam menghadapi berbagai isu-isu global.

Tulisan ini berisi pembahasan terkait peranan sains di era revolusi industri 4.0. Kajian ini merupakan kajian konseptual menggunakan studi literatur 
yang bersumber dari berbagai literatur terkait.

\section{Pembahasan}

Era revolusi industri 4.0 merupakan masa yang penuh dengan persaingan. Era dimana kehidupan manusia selalu berhubungan dengan teknologi dan informasi. Pada era revolusi industri 4.0, $75 \%$ pekerjaan melibatkan kemampuan sains, teknologi, teknik dan matematika, internet of things (IoT), dan pembelajaran sepanjang hayat (Zimmerman, 2018). Secara umum ada lima tantangan besar yang akan dihadapi pada era ini yaitu aspek pengetahuan, teknologi, ekonomi, social, dan politik (Zhou. dkk, 2015). Untuk menghadapi tantangan tersebut sumber daya manusia harus memiliki berbagai kompetensi antara lain melek sains, melek teknologi, mampu berpikir kritis, mamapu bekerjasama, kreatif dan inovatif, serta memiliki rasa percaya diri yang tinggi. Menurut Ghiffar, dkk (2018) kemampuan berpikir kritis sangat penting dikuasai karena perkembangan zaman yang semakin pesat dan kompleks menuntut manusia untuk terus berpikir dan menyelesaikan permasalahan. Dengan demikian proses berpikir kritis sangat diperlukan untuk menyelesaikan permasalahan yang dialami dalam kehidupannya sehari-hari. Selanjutnya menurut Sudira keterampilan yang juga penting dimiliki oleh peserta didik dalam menghadapi era revolusi industri 4.0 adalah keterampilan berkomunikasi baik dalam bahasa lisan atau tertulis melalui berbagai media (Mintasih, 2018).

Revolusi industry 4.0 mendorong munculnya istilah pendidikan 4.0 yaitu istilah yang merujuk pada pemanfaatan teknologi digital dalam proses pembelajaran secara optimal (Wiyono, K. \&Zakiyah, S., 2019). Menurut Almeida (2019) education 4.0 builds on the concept of learning by doing, in which students are encouraged to learn and discover differentthings in singular ways based on experimentation. Selain itu personalisasi dan fleksibilitas merupakan penciri dari pendidikan 4.0, hal ini sesuai dengan pendapat Bartolomé et al. (2018), two fundamental characteristics of education 4.0 is the personalization and flexibility. In this sense, adaptive learning systems play a fundamental role in the education 4.0 paradigm. Pendidikan 4.0 penghendaki beberapa hal diantaranya pembelajaran dikembangkan sesuai dengan kebutuhan siswa, pendidikan bukanlah transfer pengetahuan, dan pentingnya optimalisasi teknologi dalam pembelajaran. Berdasarkan beberapa penjelasan tersebut maka dapat disimpulkan bahwa dalam menghadapi era revolusi industri 4.0 perlunya pembenahan pada bidang pendidikan melalui peningkatan kualitas pembelajaran tak terkecuali pada pendidikan sains.

Sains di era revolusi industri 4.0 berperan dalam mendorong peserta didik untuk mampu mengaplikasikan pemahamannya akan sains untuk menghasilkan suatu karya teknologi yang bermanfaat dalam pemenuhan kebutuhan hidup manusia, hal tersebut mengingat karena teknogi merupakan aplikasi dari sains. Ini sependapat dengan pernyataan Bryan et al. (2016) The engineering design or engineering practices related to relevant technologies requires the use of scientific and mathematical concepts through design justification. Melalui sains peserta didik berlatih mengembangkan kemampuan berpikir secara sistematis, logis, dan kritis. Selanjutnya melalui sains peserta didik juga dilatih untuk terus berinovasi melakukan penemuan dan rekayasa dengan menerapkan berbagai langkah kerja ilmiah. Engineering requires the use of scientific and mathematical concepts to address the types of illstructured and open-ended problems that occur in the real world (Sheppard et al., 2009), penggunaan pemahaman sains dalam kegiatan rekayasa teknologi diperuntukan untuk menentukan upaya terhadap penyelesaian masalah.

Pada aplikasi di lapangan, peningkatan kualitas pembelajaran sains merupakan salah satu tantangan bagi pendidik karena dihadapkan pada tantangan bagaimana menyiapkan sumber daya manusia yang adaptif terhadap perkembangan zaman yaitu SDM yang mampu menyesuaikan diri dengan perkembangan ilmu pengetahuan dan teknologi di mana teknologi informasi telah menjadi bagian yang tak terpisahkan dari kehidupan manusia saat ini. Segala hal 
menjadi tanpa batas dengan penggunaan daya komputasi dan data yang tidak terbatas, karena dipengaruhi oleh perkembangan teknologi digital yang massif.

Harus disadari bahwa perkembangan teknologi digital yang semakin luas dapat dengan cepat merubah pola pikir, namun harus menjadi perhatian bahwa walaupun segala hal telah berbasis teknologi yang harus diperhatikan pada pembelajaran di era digital ini bukan tentang digitalnya melainkan bagaimana membentuk pola pikir dan kebiasaan berpikir, dengan demikian pembelajaran sains memiliki konsekuensi untuk senantiasa mengembangkan kemampuan berpikir peserta didik dalam setiap langkah pembelajarannya melalui pemanfaatan teknologi. Selanjutnya, semakin pesatnya perkembangan teknologi digital selain memberikan dampak positif juga dapat memberikan dampak negative pada nilai yang dimiliki oleh peserta didik sehingga penanaman terhadap nilai-nilai pendidikan juga menjadi tantangan tersendiri bagi pendidikan sains di era ini.

Seorang pendidik dalam mengimplementasikan pembelajaran sains tidak cukup hanya sebatas melakukan transfer pengetahuan saja melainkan perlu melakukan perubahan pola pembelajaran yang lebih menitik beratkan pada penggunaan teknologi dan menekankan pada siswa dalam menemukan dan menghasilkan sebuah karya yang inovatif dan bermanfaat dalam mengatasi permasalahan lingkungan. Hal ini karena ada begitu banyak kompetensi yang harus dimiliki oleh peserta didik untuk hidup di lingkungan masyarakat yang tidak bisa hanya didapat melalui transfer ilmu saja.

Pada implemetasi pembelajaran sains di era pendidikan 4.0 penerapan pembelajaran STEM merupakan salah alternative karena dapat melatih siswa dalam menerapkan pengetahuannya untuk membuat desain sebagai bentuk pemecahan masalah terkait lingkungan melalui memanfaatkan teknologi, sehingga dapat dikatakan bahwa melalui pembelajaran STEM peserta didik dilatih untuk dapat melek sains dan teknologi. STEM education, which provides the integration of disciplines of science, technology, engineering and mathematics, is an innovative approach and supports the upbringing of science and technology literate individuals (Erdogan, I \& Ciftci, A., 2017). Pembelajaran STEM juga dapat melatih kemandirian siswa serta dapat meningkatkan keterampilan berpikir tingkat tinggi dan prestasi siswa dalam proses belajarnya, ini sesuai dengan hasil penelitian yang dilakukan oleh stohlmann et al. bahwa research shows that integrated STEM education can make learning more relevant and meaningful for students, STEM can improve students' attitudes toward STEM subjects, improve higher level thinking skills, and increase achievement (E. H. M. Shahali et al., 2016).

\section{Kesimpulan}

Dalam menghadapi revolusi industry 4.0 pendidikan sains memiliki peran penting dalam menghasilkan sumberdaya manusia yang unggul baik secara soft skill maupun hard skill dan adaptif, melalui pemahamannya akan konsep sains dan pemanfaatan teknologi peserta didik diarahkan untuk menghasilkan karya untuk menyelesaikan permasalahan yang muncul dalam kehidupan sehari-hari.

\section{Daftar Pustaka}

Almaeda, F. (2019). The Role of Serious Games, Gamificationand Industry 4.0 Tools in the Education 4.0 Paradigm. Contemporary Educational Technology, 10(2), 120-136.

Bartolomé, A., Castañeda, L., \& Adell, J. (2018). Personalisation in educational technology: The absence of underlying pedagogies. International Journal of Educational Technology in Higher Education, 15(14), 1-17.

Bryan, L. A., Moore, J. T., Johnson, C. C., \& Roehrig, G. H. (2016). Integrated STEM Education. In Johnson, C. C, Peters-Burton, E. E., \& Moore, T. J. (Ed.), STEM Road Map: A Framework for Integrated STEM Education (pp.23-37). New York \& London: Routledge, Taylor \& Francis Group. 
E. H. M. Shahali et al. (2016). STEM learning through engineering design: Impact on middle secondary student's interest toward STEM. EURASIA Journal of Mathematics Science and Technology Education, 13(5), 1189-1211.

Erdogan, I \& Ciftci, A. (2017). Investigating the Views of Pre-Service Science Teachers on STEM Education Practices. International Journal of Environmental and Science Education, 12(5),1055-1065.

Ghiffar, dkk. (2018). Model pembelajaran berbasis blended learning dalam meningkatkan critical thinking skills untuk menghadapi era revolusi industri 4.0. Prosiding Seminar Nasional Pendidikan 2018, 85-94. STKIP Andi Matappa Pangkep.

Mintasih, D. (2018). Mengembangkan literasi informasi melalui belajar berbasis kehidupan terintegrasi PBL untuk menyiapkan calon pendidik dalam menghadapi era revolusi industri 4.0. Elementary islamic teacher journal, 6(2), 271-290.

Permatasari, A. (2016). STEM Education: Inovasi dalam Pembelajaran Sains. Seminar Nasional Pendidikan Sains (SNPS), 23-34. Semarang: Universitas Sebelas Maret.

Sheppard, S. D, Macantangay, K., Colby, A. \& Sullivan, W. M. (2009). Educating engineers: Designing for the future of the field. San Francisco, CA: Jossey-Bass.

Subekti, H., dkk. (2018). Mengembangkan literasi informasi melalui belajar berbasis kehidupan terintegrasi stem untuk menyiapkan calon guru sains dalam menghadapi era revolusi industri 4.0: revieu literatur. Education and Human Development Journal, 3(1), 81-90. program studi pendidikan fisika, 114. Banjarmasin: FKIP ULM.

Zhou, K., Taigang L., \& Lifeng, Z. (2015). Industry 4.0: Towards future industrial opportunities and challenges. In Fuzzy Systems and Knowledge Discovery (FSKD). IEEE 12th International Conference, 2147-2152.

Wiyono, K. \&Zakiyah, S. (2019). Pendidikan Fisika Pada Era Revolusi Industri 4.0 Di Indonesia. Seminar nasional pendidikan 